\title{
10-13 Yaş Grubu Çocukların Müzik Yaşantısına Yönelik Tutum Ölçeğinin Geçerlik Güvenirlik Çalışması
}

\author{
DOI: $10.26466 /$ opus.834894
}

*

\author{
Hasan Hakan Okay * - Özge Gençel Ataman ** - Barış Kardeş *** \\ * Dr.Öğr.Üyesi, Balıkesir Üniversitesi Necatibey Eğitim Fakültesi, Balıkesir/Türkiye \\ E-Posta: okay@balikesir.edu.tr \\ ORCID: $\underline{0000-0002-3465-1325}$ \\ ${ }^{* *}$ Doç.Dr., Balıkesir Üniversitesi Necatibey Eğitim Fakültesi, Balıkesir/Türkiye \\ E-Posta: ogencel@balikesir.edu.tr \\ ORCID: $\underline{0000-0002-4621-8609}$ \\ *** Öğr.Gör.Dr., Balıkesir Üniversitesi Necatibey Eğitim Fakültesi, Balıkesir/Türkiye \\ E-Posta: bariskardes@balikesir.edu.tr \\ ORCID: $0000-0002-4802-5202$
}

\begin{abstract}
Öz
Çocukların müzikle ilişkili sosyal yaşantıları ve bu yaşantının içinde müzik yapmaya dönük tutumları, gerek müzik eğitimi için gerekse müzik eğitiminin sosyal psikoloji ile kesiştiği bir çalışma alanında önemli tartışmalar üretebilir. Ancak literatürde bu tartışmalara bulgu sunacak bir ölçme aracı bulunmamaktadır. Bu çalışmanın amacı, çocukların şarkı söylemek, müzik dinlemek, çalgı çalmak gibi çeşitli müzikal pratiklerini sosyal bağlamda ele alan, çocukların müzik yaşantılarına yönelik geçerli ve güvenilir bir "Müzik Yaşantısı Tutum Ölçeği" geliştirmektir. 13 tutum maddesinden oluşan taslak ölçeğe uygulanan açımlayıcı faktör analizinde, faktörlerin mümkün olduğunca güçlü maddelerden oluşmasını sağlamak amacıyla faktör yük sınır değeri 0.50 olarak belirlenmiştir. Açımlayıcı faktör analizi sonucunda 1 maddenin (10. Madde) faktör yük sinır değerinin (0.50) altında kaldı̆̆g sonucuna varılmış ve madde ölçekten çıkarılmıştır. Yeniden yapılan açımlayıcı faktör analizi sonuçlarına göre 12 maddeden oluşan ölçeğin, 3 faktörlü bir yapıya sahip olduğu ve faktörlerin toplam varyansın \% 59.838'ini açıkladığı belirlenmiştir. Faktörler altına yüklenen maddelerden ve konunun kuramsal yapısından yola çıkılarak ölçekteki faktörler; Müzikal çevreye yönelik tutum, müzik dersine yönelik tutum ve şarkı yaşantısına yönelik tutum olarak adlandırılmıştır. 3 faktör altında yer alan 12 maddelik ölçeğin tümü için Cronbach'ın alfa güvenirlik katsayısı 0.860 bulunmuştur. Ölçeğin psikometrik özellikleri dikkate alındığında, çocukların müzik yaşantısına yönelik tutumlarının ölçülmesinde geçerli ve güvenilir bir ölçme aracının geliştirildiği düşünülmektedir.
\end{abstract}

Anahtar Kelimeler: Müzik eğitimi, tutum, müzikal yaşantl, müzikal çevre 


\title{
Validity and Reliability Study of the Attitude Scale Towards Music Experience of 10-13 Age Group Children
}

\begin{abstract}
Children's music-related social lives and their attitudes towards making music within this life can produce important discussions both for music education and in a field of study where music education intersects with social psychology. However, there is no measurement tool in the literature to present findings to these discussions. The aim of this study is to develop a valid and reliable "Musical Life Attitude Scale" that addresses children's musical practices such as singing, listening to music, and playing musical instruments in a social context.

As a result of the item analysis conducted in the draft scale consisting of 13 attitude items, no items with low correlation coefficient were found. In the exploratory factor analysis, factor load limit value was determined as 0.50 in order to ensure that the factors consist of items as strong as possible. As a result of the exploratory factor analysis, it was concluded that 1 item (item 10) was below the factor load limit value (0.50) and the item was removed from the scale. According to the results of the re-made exploratory factor analysis, it was determined that the scale consisting of 12 items has a 3-factor structure and the factors explain $59.838 \%$ of the total variance. The factors in the scale based on the items loaded under the factors and the theoretical structure of the subject; Attitude towards the musical environment has been named as attitude towards music lesson and attitude towards song life. Cronbach's alpha reliability coefficient was found 0.860 for the whole scale of 12 items under 3 factors. Considering the psychometric properties of the scale, it is thought that a valid and reliable measurement tool was developed to measure children's attitudes towards music life.
\end{abstract}

Keywords: Music education, attitude, musical life, musical environment 


\section{Giriş}

Müzik eğitiminin öznesi olarak öğrenen, eğitim süreci boyunca çok çeşitli duyuşsal unsurlarla etkileşerek eğitim süreci boyunca gelişimini sürdürür. Bugün çeşitli gelişimsel kuramlara bakıldığında bazı özelliklerin doğuştan gelen ve değiştirilemez olduklarının kabul edilmesinin yanında, yaşantıdaki çevresel etkenlerin ve uyaranların da önemli gelişimsel faktörler olduğu vurgulanmaktadır (Özdemir vd., 2012). Özellikle 20. yüzyıla bakıldığında kişilik, eğilimler, fiziksel bazı özellikler gibi çok çeşitli unsurların, zamanla değişen bă̆lamlarda ele alındığı görülmektedir. Örneğin müzik yeteneğini ölçmeye yönelik psikometrik ölçme araçlarının geliştirilmesi sürecine bakıldığında, önce yeteneğin genetik kaynaklı olduğuna yönelik görüşlerin benimsendiği, ancak 1980'lerden sonra çevrenin etkisinin ve yeteneğin gelişimsel olduğuna ilişkin fikirlerin daha baskın olduğu göze çarpmaktadır (Hallam, Shaw, 2002). Bu görüşlere bir kanit olarak, Crozier' in eğitimle ve içinde bulunulan çevrenin müzikal etkileriyle mutlak kulak işitme becerisinin kazanılabilineceğini gösterdiği araştırması sunulabilir (Crozier, 1997).

90'lı yıllarda yeteneğin türleri olduğu (Gardner, 1983) veya yeteneğin farklı özelliklerinin de olabileceğine dönük kuramlarla (Renzulli, 1986) zenginleşen farklı yaklaşımlar, yetenek kavramını anlamak için artık çevrenin ve doğuştan gelen özelliklerin birlikte ele alınması gerektiğine işaret etmiştir. Doğuştan gelme veya çevreden etkilenme konusunda netleşen bu bakış aç1sıyla, artık bilim insanları gelişimsel yeni bir paradigma değişimine doğru da ilerleneceğini varsaymış (Kaufmann, Stenberg 2008); yapılan çalışmalarda bu eğilim sergilenmiştir (Dai, 2018). Bu görüşleri destekleyen güncel kanttlar ise epigenetik çerçevede genetik ve çevre etkilerinin beraberce müzik yeteneğini etkilediğini ortaya koymakta (Hambrick, Tucker-Drob, 2015); hatta çevrenin veya genetiğin ne oranlarda etkili olduklarını da keşfetmeye çalışmaktadır (Seesjärvi vd., 2016). Yeni bir çalışma alanı olarak epigenetik, bu kanıta destek olan biyolojik bir bakış açısını temel alır. Epigenetik bağlamda çevre ve organizmanın yaşam boyu bir etkileşim içinde olduklarına yönelik yeni kanıtlar ortaya konarak, "çevre mi, gen mi tartışması" sonlanmaya yaklaşmıştır (Moore, 2015). Dolayısıyla epigenetiğin de biyolojik kanıtlarıyla, bir süredir psikoloji çalışmalarının geldiği noktaların artık kesişmekte olduğu; çevrenin ve doğuştan gelen özelliklerin birbiriyle yaşam boyu etkileştiği ve gelişimsel unsurların da işe koşulduğuna yönelik genel bir konsensus olduğu söylenebilir. 
Tüm yaşantısı boyunca müzikle çeşitli koşullarda ve düzeylerde etkileşimde bulunan modern insan için, bu kuramsal yaklaşımlar, çevrenin metabolizma üzerindeki etkilerine ilişkin kantlardan dolayı sosyal psikolojinin önemini pekiştirmiştir. Bu eğilim önemli müzik psikologlarının da dikkatini çekmiş görünmektedir. Örneğin Hargreaves ve North (1999) müzik psikolojisinde sosyali tanımlama çabalarını sergilerken, müziğin bilişsel ve duyuşsal etkilerinden çok, sosyal etkilerinin dikkate alınması gerektiğini savunmuşlardır. Dolayısıyla müzikal bir yaşantının içerisinde çevrenin ve sosyalleşmenin etkileri aranabilir.

Eğitim kurumlarının toplum yaşantısına girmesiyle birlikte, binlerce yıldan bu yana insan ve toplumun bir parçası olan müzik, eğitim programlarında yer alarak eğitim sürecinin formal ortamı olmuştur. Dolayısıyla farklı sosyal törenlerde ve dini törenlerde çeşitli amaçlarla zaten yaşamakta olan müzik, eğitim yaşantısında da bir rol üstlenmeye başlar. Bununla birlikte formal eğitim yaşantısında (örneğin değerler eğitimi gibi) gerek sosyalleşmede gerekse bireyin üzerindeki duyuşsal etkilerinden dolayı, müziğin işlevselliğine yönelik çok çeşitli örtük eğitsel anlamlar ve amaçlar yüklenmiştir. Hallam'a (2010) göre yapılan araştırmalardan elde edilen kanıtlar, yaşam boyunca önemli bir rol oynayan müziğin insanlar üzerindeki tipik etkilerinin entelektüel olmaktan çok duygusal olduğunu ve müziğe etkin olarak katılanların bu duyuşsal boyuttan en çok faydalananlar olduğunu göstermektedir. Başka bir ifadeyle müzik yaşantısına etkin olarak katılım, duyuşsal faydayı arttırmaktadır. Bu bilgiler ışığında müziğin eğitim programlarında sadece bir konu olarak kalmayıp, sosyal boyutuyla güçlü bir duyuşsal etken olduğu; özellikle müzik yaşantısının bir parçasına ait olmanın da bu duyuşsal etkileri arttırdığı söylenebilir.

Bilim insanları duyuşsal özellikleri de dikkate alarak sosyal psikoloji müzikal çevre, müzik deneyimi ve müzikal katılım konularıyla, insanın müzik yaşantısını çerçevelemeye çalışmaktadırlar. Müzikal çevre, ağırlıkla öğrencilerin evdeki müzikal yaşantılarını anlamaya çalışan bir alan (Brand, 1986), olarak şekillenmiş görünmekle birlikte, okuldaki müzikal yaşantılarını ele alan araştırmalar da bulunmaktadır (Katie, 2008). Müzikal pratiklere yönelik çeşitli eğilimleri ifade eden müzik deneyimi (Werner vd., 2006) ve daha çok müzik pratiklerinde görev almaya ve müzik dinleme gibi yaşantılara işaret eden müzikal katılım (Pitts, 2005) birbirlerine benzer çalışma alanlarıdır. Tüm 
bu alanlara bakıldığında bilişsel ve devinimsel unsurların müziğin doğasına uyumlu bir şekilde duyuşsal unsurlarla etkileşimde olduğu görülebilir.

Müziğin yukarıda dile getirilen sosyal ve duyuşsal özellikleriyle tanımlanması ve müzikal çevre ve müzikal katılımla, deneyime dayalı niteliklerinin anlatımı, müzik yaşantısına yönelik bir tutum durumunun tartışılma gereğini doğurmuştur. Böylelikle eğer müzikal yaşantrya yönelik tutumun belirlenmesi ve ölçülmesi mümkün olursa, çok çeşitli değişkenlerle, müzik yaşantısını etkileyen faktörler ele alınabilir. Aynı zamanda böyle bir ölçüm, öğrencilerin bir şekilde dışa vurmadıkları müziğe yönelik olumlu eğilimlerinin keşfedilmesi için de öğretmenlere bir araç olarak yeni olanaklar sunabilir. Dile getirilen bağlamda bu araştırmada, çocukların şarkı söylemek, müzik dinlemek, çalgı çalmak gibi çeşitli müzikal pratiklerini sosyal bağlamda ele alan, çocuklara yönelik geçerli ve güvenilir bir Müzik Yaşantısı Tutum Ölçeği geliştirilmesi amaçlanmaktadır.

\section{Yöntem}

$\mathrm{Bu}$ araştırma bir ölçek geliştirme çalışmasıdır. Çalışmanın ölçek geliştirme aşamasında, betimsel araştırma olarak tarama modelinden yararlanılmıştır. Araştırma seçilmiş bir örneklem yoluyla nicel bir betimleme amacı taşımaktadır. Buna göre Creswell' in (2017) tarama modeli tanımı dikkate alınarak çalışmanın modeli, nicel ve betimsel bir araştırma olarak şekillenmiştir.

\section{Örneklem}

Bu araştırmanın çalışma grubu, Balıkesir ili merkez ilçelerindeki devlete bağlı ortaokullarda öğrenim görmekte olan 524 ortaokul öğrencisinden oluşmaktadır. Tablo 1, örneklemin demografik özelliklerini taşımaktadır.

Tablo 1. Çalışma grubuna ilişkin demografik bilgiler

\begin{tabular}{lll}
\hline Cinsiyet & $\mathbf{N}$ & \% \\
\hline Kız & 282 & 53.82 \\
Erkek & 242 & 46.18 \\
Toplam & 524 & 100.00 \\
\hline Yaş & $\mathbf{N}$ & $\%$ \\
\hline 10 & 165 & 31.49 \\
11 & 152 & 29,00 \\
12 & 102 & 19.47 \\
13 & 105 & 20.04 \\
Toplam & 524 & 100.00 \\
\hline
\end{tabular}


Tablo 1'e bakıldığında, çalışmaya katılan öğrencilerin \% 53.82'sinin Kız, \% 46.18'inin Erkek öğrencilerden oluştuğu, \% 31.49'unun 10 yaşında, \% 29.00'unun 11 yaşında, \% 19.47'sinin 12 yaşında ve \% 20.04'ünün ise 13 yaşında oldukları anlaşılmaktadır. 10-13 yaş grubundan oluşan veri kaynağı aynı zamanda ilköğretim II. kademe öğrencileridir.

\section{Bulgular}

\section{Ölçeğin Geliştirilmesi}

Ölçeğin geliştirme aşamasında ilk olarak, ortaokul kademesinde öğrenim görmekte olan 121 öğrenciye "Müziğe ve müzik dersine ilişkin görüş ve beklentileriniz nelerdir?" konulu bir kompozisyon yazdırılmıştır. Öğrencilerin konu ile ilgili yazmış oldukları kompozisyonlar içerik analizi yöntemi ile analiz edilmiş ve analiz sonucunda öğrencilerin müzik yaşantllarına yönelik tutum ifadeleri maddeleştirilmiştir. Öğrencilerin müzik yaşantılarına ilişkin tutum ifadelerinin yanında konu ile ilgili literatür ve tutum ile ilgili ölçekler de incelenerek 13 maddeden oluşan bir madde havuzu oluşturulmuştur. Ölçeğin görünüş ve kapsam geçerliği açısından 2 müzik eğitimi ve 1 istatistik uzmanı olmak üzere 3 öğretim üyesinin görüşlerine başvurulmuştur. Uzman görüşleri doğrultusunda ölçekteki tüm maddelerin müzik yaşantısına ilişkin tutumu ölçmede uygun olduğu, gerekli verileri toplayabileceği ve istenilen özelliği ölçer göründüğü sonucuna varılmıştır. Ölçeğin kapsam geçerliğine yönelik olarak Davis tekniğinden yararlanılmıştır. Yurdugül (2005)'e göre Davis tekniği, uzman görüşlerini "A-Uygun, B-Madde hafifçe gözden geçirilmeli, C-Madde ciddi olarak gözden geçirilmeli ve D-Madde uygun değil" şeklinde dörtlü derecelendirmektedir. Bu teknikte aday madde için tüm uzman formlarındaki A ve B'lerin toplamı, toplam uzman sayısına bölünerek maddeye ilişkin "kapsam geçerlik indeksi" (KGI) elde edilmektedir ve bu değer 0.80 değeri ölçüt olarak kabul edilmektedir.

Tablo 2'ye bakıldığında, 3 öğretim üyesinin değerlendirmelerine göre ölçekteki tüm maddelerin kapsam geçerlik oranlarının en yüksek değer olan 1.00 olduğu görülmektedir. Bu bağlamda hesaplanan değerlerin asgari değerden (0.80) fazla ve en yüksek değerde olması uzmanlar arasında uyum olduğunu ve kapsam geçerliği açısından ölçekten madde atılmaması gerektiğini göstermektedir. Görünüş ve kapsam geçerliği alınan ölçeğe daha sonra, 
ölçeğin amacı ve cevaplama şeklini açıklayan bir yönerge eklenmiş ve ölçekteki her ifade için "Evet", "Fikrim yok" ve "Hayır" olmak üzere 3'lü likert eklenerek ölçekteki maddeler sıralanmıştır.

Tablo 2. Ölçek maddelerinin uzman görüşleri doğrultusunda kapsam geçerlik oranları

\begin{tabular}{llllll}
\hline Madde & A-Uygun & $\begin{array}{l}\text { B-Hafifçe Gözden } \\
\text { geçirilmeli }\end{array}$ & $\begin{array}{l}\text { C-Ciddi olarak } \\
\text { gözden geçirilmeli }\end{array}$ & $\begin{array}{l}\text { D-Uygun } \\
\text { değil }\end{array}$ & $\begin{array}{l}\text { Kapsam } \\
\text { Geçerlik Oran }\end{array}$ \\
\hline $\mathbf{1}$ & 3 & 0 & 0 & 0 & 1.00 \\
$\mathbf{2}$ & 3 & 0 & 0 & 0 & 1.00 \\
$\mathbf{3}$ & 3 & 0 & 0 & 0 & 1.00 \\
$\mathbf{4}$ & 3 & 0 & 0 & 0 & 1.00 \\
$\mathbf{5}$ & 3 & 0 & 0 & 0 & 1.00 \\
$\mathbf{6}$ & 3 & 0 & 0 & 0 & 1.00 \\
$\mathbf{7}$ & 3 & 0 & 0 & 0 & 1.00 \\
$\mathbf{8}$ & 3 & 0 & 0 & 0 & 1.00 \\
$\mathbf{9}$ & 3 & 0 & 0 & 0 & 1.00 \\
$\mathbf{1 0}$ & 2 & 1 & 0 & 0 & 1.00 \\
$\mathbf{1 1}$ & 3 & 0 & 0 & 0 & 1.00 \\
$\mathbf{1 2}$ & 3 & 0 & 0 & 0 & 1.00 \\
$\mathbf{1 3}$ & 3 & 0 & 0 & 0 & 1.00 \\
\hline
\end{tabular}

\section{Ölçme Aracının Güvenirlik Çalışması}

Madde analizinde madde toplam korelasyon katsayısının iliş̧i düzeyi incelenirken, Büyüköztürk'ün (2008) yaklaşımı dikkate alınmıştır. 13 maddeden oluşan ölçeğe uygulanan madde analizi sonucunda madde toplam korelasyon katsayısı 0,30'un altında olan hiçbir madde ile karşılaşılmamış bu nedenle madde analizi sonucunda ölçekten herhangi bir maddenin atılmasına ihtiyaç duyulmamıştır. 13 maddeden oluşan ölçeğe ilişkin istatistik değerlerine Tablo 3'de yer verilmiştir.

Tablo 3. Madde ortalama, madde standart sapma ve madde toplam korelasyon değerleri

\begin{tabular}{|c|c|c|c|}
\hline Madde & Madde ortalaması & Madde standart sapması & Madde toplam korelasyonu \\
\hline 1 & 2.5670 & .70799 & .499 \\
\hline 2 & 1.8184 & .80598 & .551 \\
\hline 3 & 2.7017 & 63888 & .472 \\
\hline 4 & 2.1740 & .83330 & .606 \\
\hline 5 & 2.6080 & .71403 & .537 \\
\hline 6 & 2.4627 & .78954 & .495 \\
\hline 7 & 2.2996 & .82499 & .565 \\
\hline 8 & 2.3142 & .81627 & .572 \\
\hline 9 & 2.4242 & .81952 & .383 \\
\hline 10 & 2.2767 & .85113 & .510 \\
\hline 11 & 2.3021 & .79946 & 620 \\
\hline 12 & 1.6520 & .78546 & .540 \\
\hline 13 & 2.3927 & .77298 & .634 \\
\hline
\end{tabular}


13 maddeden oluşan ölçeğin Cronbach'ın alfa güvenirlik katsayısı $(\alpha)=$ 0.867 bulunmuştur. Literatürde Cronbach'ın alfa güvenirlik katsayısının yorumlanması için farklı sınıflamalar yer almaktadır. George ve Mallery (2003) güvenirlik katsayısına ilişkin ölçüt değerleri; $0.81<\alpha<1.00$ olduğunda ölçek yüksek güvenirlikte, $0.61<\alpha<0.80$ olduğunda ölçek orta güvenirlikte, $0.41<$ $\alpha<0.60$ olduğunda ölçek düşük güvenirlikte ve $0.00<\alpha<0.40$ olduğunda da ölçek güvenilir değil şeklinde ifade etmektedir. Bu ölçüt değerler dikkate alındığında, ölçeğin yüksek güvenirlikte olduğu ve çocukların müzik yaşantılarına yönelik tutumlarının belirlenmesinde güvenirlik düzeyi yüksek ölçme sonuçlarına ulaşılabileceğini göstermektedir. 13 maddeden oluşan ölçeğin Cronbach'ın alfa güvenirlik katsayısına ilişkin değerlere Tablo 4'de yer verilmiştir.

Tablo 4. Cronbach'ın alfa güvenirlik testi tablosu

\begin{tabular}{ll}
\hline Madde Sayısı & Cronbach'ın Alfa Güvenirlik Katsayısı \\
\hline 13 & 0.867 \\
\hline
\end{tabular}

\section{Ölçme Aracının Geçerlik Çalışması}

Madde analizi sonrasında 13 maddeden oluşan ölçeğin faktör analizine uygunluğunun belirlenebilmesi için Kaiser-Meyer-Olkin (KMO) Örneklem Yeterliliği Testi ve Barlett Küresellik Testinden yararlanılmıştır. KMO değerinin 0.60 ve üstünde olması örneklemin faktör analizi için yeterli olduğunu göstermektedir (Gürbüz ve Şahin, 2016). Durmuş, Yurtkoru ve Çinko (2016) ise KMO örneklem yeterliğinin kabul edilebilir alt sınırının 0,50 olduğunu ve 0.80 ve yukarısı için $\mathrm{KMO}$ değerinin mükemmel kabul edildiğini belirtmektedir. Ölçekte maddelerin belli temalarda toplanma durumunu başka bir ifadeyle korelasyonel ilişkilerin faktör analizi yapmak için yeterliğini belirlemek üzere Barlett Küresellik testi de uygulanmıştır. 13 maddeden oluşan ölçeğin $\mathrm{KMO}$ değerinin 0.80'nin üzerinde olması $(K M O=0,876)$ ve Barlett testinin de 0.05 önem derecesinde anlamlı bulunması $(p=0.000)$ veri setinin faktör analizine uygunluğunu göstermektedir. 13 maddelik ölçeğin KMO ve Barlett testi değerleri Tablo 5'de sunulmuştur.

Tablo 5. KMO ve Barlett testi tablosu

\begin{tabular}{lll}
\hline Kaiser-Meyer-Olkin Testi (KMO) (Örneklem Yeterliliği Testi) & 0.876 \\
\hline \multirow{2}{*}{ Bartlett Testi (Bartlett's Test) (Bartlett Küresellik Testi) } & Ki Kare & 2345.816 \\
& $p$ & 0.000 \\
\hline
\end{tabular}


Faktör analizinde faktör yüklerinin 0.32 'nin üzerinde olması önerilmektedir (Gürbüz ve Şahin, 2016). Bir başka değişle, faktör yük değeri sınırı 0.30'a kadar indirilebilir ancak faktör yük değerinin 0.45 ya da daha yüksek olması seçim için iyi bir ölçüttür (Büyüköztürk, 2008). Araştırmacılar tarafından faktör yük değerlerinin yüksek tutulması, faktörlerin olabildiğince güçlü maddelerden oluşmasını sağlamaktadır. Bu nedenle ölçeğin faktör analizi sırasında faktör yük değeri sınırı 0.50 olarak belirlenmiştir.

Tablo 6. 13 Maddelik ölçeğin faktör yük değerleri

\begin{tabular}{llll}
\hline Maddeler & 1.Faktör & 2.Faktör & 3.Faktör \\
\hline 11 & .721 & .346 & .079 \\
2 & .715 & .059 & .306 \\
12 & .657 & .162 & .234 \\
1 & .654 & .356 & -.089 \\
10 & .472 & .184 & .390 \\
3 & .098 & .766 & .061 \\
7 & .133 & .691 & .309 \\
8 & .309 & .668 & .126 \\
13 & .497 & .618 & .056 \\
5 & .233 & .585 & .248 \\
6 & .091 & .233 & .782 \\
9 & .064 & .084 & .773 \\
4 & .394 & .173 & .681 \\
\hline
\end{tabular}

Tablo 6' da 13 maddeden oluşan ölçeğin faktör analizi sonucundaki faktör yük değerlerine bakıldığında, 10. maddenin faktör yük değerinin faktör yük sınırı olarak belirlenen 0.50 değerinin altında olduğu anlaşılmıştır. Ölçeğin faktör analizindeki dönüşümlü faktör yükleri sonuçlarına göre yine 10. maddenin birden fazla faktörde (1 ve 3. faktörlerde) binişik yapıda olduğu belirlenmiştir. Bu nedenle 10. Madde, ölçeğin olabildiğince güçlü maddelerden oluşması amacına yönelik olarak ve maddenin ölçeğin güvenirliğini düşürebileceğinden yola çıkılarak ölçekten çıkarılmış ve kalan 12 madde ile ölçeğe nihai şekli verilmiştir.

Tablo 7, 8, 9 ve 10'da 13 maddeden oluşan ön deneme formuna uygulanan madde analizi ve açımlayıcı faktör analizi sonucunda 1 maddenin ölçekten çıkarılmasıyla oluşturulan 12 maddelik Çocukların Müzik Yaşantısına Yönelik Tutum Ölçeği'nin son şekline ilişkin bulgu ve yorumlara yer verilmiştir. 
Tablo 7. Ölçek maddelerine ilişkin istatistikler

\begin{tabular}{llllll}
\hline No & Madde & $\begin{array}{l}\text { Madde } \\
\text { ortalaması }\end{array}$ & $\begin{array}{l}\text { Madde standart } \\
\text { sapması }\end{array}$ & $\begin{array}{l}\text { Madde toplam } \\
\text { korelasyonu }\end{array}$ & $\begin{array}{l}\text { Madde silme } \\
\text { Güvenirlik } \\
\text { katsayısı }\end{array}$ \\
\hline 1 & $\begin{array}{l}\text { Müzik dersi ile ilgili ödev yapmayı } \\
\text { seviyorum. }\end{array}$ & 2.5670 & .70799 & .497 & .851 \\
\hline 2 & Keşke sadece müzik dersi olsa. & 1.8184 & .80598 & .551 & .848 \\
\hline 3 & $\begin{array}{l}\text { Keşke keman, gitar, bağlama, piyano } \\
\text { gibi bir çalgı çalabilseydim. }\end{array}$ & 2.7017 & .63888 & .479 & .853 \\
\hline 4 & Bütün gün şarkı söylemek isterim. & 2.1740 & .83330 & .580 & .846 \\
\hline 5 & Konser izlemekten çok keyif alırım. & 2.6080 & .71403 & .531 & .849 \\
\hline 6 & Saatlerce müzik dinleyebilirim. & 2.4627 & .78954 & .492 & .852 \\
\hline 7 & $\begin{array}{l}\text { Büyüklerimin beni stk sik konsere } \\
\text { götürmesini isterim. }\end{array}$ & 2.2996 & .82499 & .570 & .846 \\
\hline 8 & $\begin{array}{l}\text { Ailemin bana çalgi dersi } \\
\text { aldırmasinı isterim. }\end{array}$ & 2.3142 & .81627 & .580 & .846 \\
\hline 9 & Her gün mutlaka müzik dinlerim. & 2.4242 & .81952 & .378 & .860 \\
\hline 11 & Müzik dersini sabırsılıkla beklerim. & 2.3021 & .79946 & .615 & .843 \\
\hline 12 & Gelecekte müzisyen olmak istiyorum. & 1.6520 & .78546 & .539 & .849 \\
\hline 13 & Müzik ile ilgili her şeyi bilmek isterim. & 2.3927 & .77298 & .630 & .842 \\
\hline Cronbach'ın Alfa Güvenirlik Katsayısı $(\boldsymbol{\alpha})=\mathbf{0 . 8 6 0}$ & & & \\
\hline
\end{tabular}

Tablo 7'de 12 maddeden oluşan nihai ölçeğin maddelerine ilişkin madde ortalama, madde standart sapma, madde toplam korelasyon ve madde silme güvenirlik katsayısı değerlerine yer verilmiştir. Maddelerin madde silme güvenirlik katsayısı değerlerine bakıldığında, güvenirlik katsayısını hiçbir maddenin olumsuz olarak etkilemediği anlaşılmaktadır. Yine tablodan anlaşılacağı gibi 12 maddeden oluşan ölçeğin Cronbach'ın alfa güvenirlik katsayısı 0.860 bulunmuştur. Özdamar (1999, akt. Yaşar, 2014)'in da belirttiği gibi güvenirlik katsayısına ilişkin ölçüt değerler 0.81 ile 1.00 arasında bir değer aldığında ölçek yüksek düzeyde güvenilir kabul edilmektedir. Bu ölçüt değerler dikkate alındığında, 12 maddeden oluşan ölçeğin yüksek düzeyde güvenirlik katsayısına sahip olduğu ve çocukların müzikal yaşantısına yönelik tutumlarının belirlenmesinde güvenirlik düzeyi yüksek ölçme sonuçlarını gösterebileceği anlaşılmaktadır. 
Tablo 8. Açımlayıcı faktör analizine ilişkin açıklanan toplam varyans değerleri

\begin{tabular}{|c|c|c|c|c|c|c|}
\hline & \multicolumn{2}{|c|}{ Başlangıç Öz Değerleri } & & \multicolumn{3}{|c|}{ Dönüştürülmüş Kareli Ağırlıklar Toplamı } \\
\hline & Toplam & Açıklanan & & Toplam & Açılanan & \\
\hline Bileşen & & Varyans \% & Birikimli \% & & Varyans \% & Birikimli \% \\
\hline 1 & 4.774 & 39.787 & 39.787 & 2.639 & 21.994 & 21.994 \\
\hline 2 & 1.383 & 11.525 & 51.312 & 2.484 & 20.700 & 42.694 \\
\hline 3 & 1.023 & 8.526 & 59.838 & 2.057 & 17.144 & 59.838 \\
\hline 4 & .922 & 7.681 & 67.519 & & & \\
\hline 5 & .716 & 5.967 & 73.486 & & & \\
\hline 6 & .560 & 4.669 & 78.155 & & & \\
\hline 7 & .542 & 4.518 & 82.673 & & & \\
\hline 8 & .507 & 4.225 & 86.898 & & & \\
\hline 9 & .452 & 3.769 & 90.667 & & & \\
\hline 10 & .426 & 3.547 & 94.214 & & & \\
\hline 11 & .364 & 3.034 & 97.248 & & & \\
\hline 12 & .330 & 2.752 & 100.000 & & & \\
\hline
\end{tabular}

Ölçeğinin toplam varyans değer tablosuna göre, faktör analizine girmiş soru sayısı Bileşen sütununda yer almaktadır. Başlangıç Öz değerleri sütunundaki Toplam sütununa bakıldığında, 1'den büyük öz değere sahip 3 bileşenin bulunduğu görülmektedir. Bu durum ölçeğin 3 alt boyuttan oluştuğunu ortaya çıkarmaktadır. Dönüştürülmüş Kareli Ağırlıklar Toplamı sütununun altında yer alan Birikimli \% sütununa bakıldığında, 3 alt boyutun toplam varyansın \% 59.838'ini açıklandığı anlaşılmaktadır. Bu bulguya göre, ortaya çıkan 3 faktör, maddelerdeki toplam varyansı ve ölçeğe ilişkin varyansın çoğunu açılamaktadır.

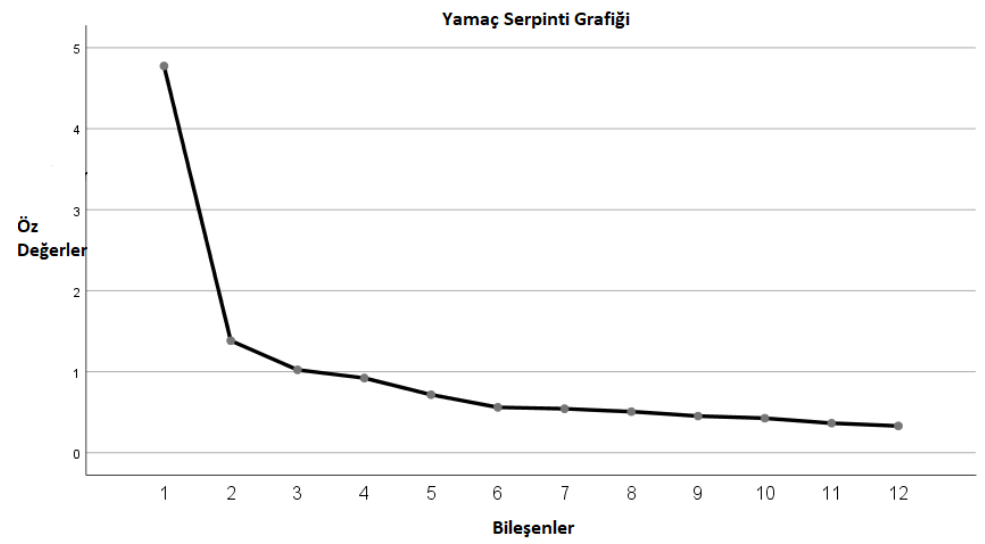

Şekil 1. Çocuklarnn müzik yaşantısına yönelik tutum ölçeğinin yamaç serpinti grafiği 
Çocukların müzik yaşantısına yönelik tutum ölçeğinin yamaç serpinti grafiği incelendiğinde, 3 . bileşenden sonra varyans değerlerinin birbirlerine yakınlaştı̆̆ı, eğri eğiminin düzleşmeye başladığı ve öz değerlerin de 1'in altına düştüğü anlaşılmaktadır. Bu durum, ölçekteki faktör belirleme noktasınin 3 olduğunu destekler niteliktedir.

Tablo 9. Açımlayıcı faktör analizine ilişkin faktör döndürme sonuçlan

\begin{tabular}{llll}
\hline Faktörler & & & \\
\hline Maddeler & 1. Faktör & 2. Faktör & 3. Faktör \\
\hline 3 & .752 & .107 & .056 \\
7 & .700 & .121 & .307 \\
8 & .654 & .323 & .129 \\
13 & .625 & .487 & .051 \\
5 & .613 & .199 & .237 \\
2 & .050 & .739 & .335 \\
11 & .357 & .715 & .087 \\
12 & .155 & .674 & .256 \\
1 & .366 & .649 & -.081 \\
6 & .237 & .088 & .791 \\
9 & .079 & .072 & .784 \\
4 & .199 & .363 & $\mathbf{. 6 7 2}$ \\
\hline
\end{tabular}

Ölçeğin açımlayııı faktör analizine ilişkin faktör döndürme sonuçları incelendiğinde, ölçek maddeleri hangi faktör altında en büyük faktör yüküne sahipse maddelerin o faktör altında yer aldığı anlaşılmaktadır. Faktör analizi sonucunda elde edilen faktör döndürme sonuçlarına göre, 3, 7, 8, 13 ve 5 . maddelerin birinci faktör altında, 2, 11, 12 ve 1 . maddelerin ikinci faktör altında ve 6, 9 ve 4 . maddelerin ise üçüncü faktör altında yer aldığı görülmektedir.

Tablo 10. Ölçeğin faktör ve güvenirlik analizi sonuçlan

\begin{tabular}{llll}
\hline $\begin{array}{l}\text { Faktörün } \\
\text { Adı }\end{array}$ & $\begin{array}{l}\text { Ölçek } \\
\text { Maddeleri }\end{array}$ & $\begin{array}{l}\text { Açıklanan } \\
\text { Varyans(\%) }\end{array}$ & $\begin{array}{l}\text { Güvenirlik Cronbach'ın } \\
\text { Alfa Katsayısı }(\boldsymbol{\alpha})\end{array}$ \\
\hline 1.Faktör - Müzikal çevreye yönelik tutum & $3,7,8,13,5$ & 39.787 & 0.787 \\
2.Faktör - Müzik dersine yönelik tutum & $2,11,12,1$ & 11.525 & 0.751 \\
3.Faktör - Şarkı yaşantısına yönelik tutum & $6,9,4$ & 8.526 & 0.728 \\
\hline
\end{tabular}

Faktörler, barındırdıkları maddelerin amaçları, ifadeleri ve konu ile ilgili literatür dikkate alınarak isimlendirilmiştir. Faktörlere verilen isimler, her faktörün altında yer alan maddeler, faktörlerin açıkladıkları varyans ve yine faktörlerin güvenirlik katsayıları Tablo 9 aracılığı ile sunulmuştur. Tablo 9'a göre "Müzikal çevreye yönelik tutum" olarak isimlendirilen 1. Faktör 3, 7, 8, 13 ve 5 . maddeler olmak üzere 5 maddeyi kapsamaktadır. Bu faktör toplam 
varyansın \% 39.787'sini oluşturmaktadır ve faktörün güvenirlik katsayısı 0.787 olarak bulunmuştur. 2. Faktör "Müzik dersine yönelik tutum" olarak isimlendirilmiştir ve faktör 2, 11, 12 ve 1 . maddelerden oluşmaktadır. 2. Faktör toplam varyansın \% 11.525'ini açıklamaktadır ve faktörün güvenirlik katsayısı 0.751 olarak bulunmuştur. "Şarkı yaşantısına yönelik tutum" olarak isimlendirilen 3. Faktör ise 6, 9 ve 4 olmak üzere 3 maddeden oluşmaktadır. 3. Faktör toplam varyansın \% 8.526'sını açıklamaktadır ve faktörün güvenirlik katsayısı 0.728 olarak bulunmuştur.

\section{Tartışma ve Sonuç}

Çocukların müzik yaşantısına yönelik tutum ölçeğinin geliştirilmesinin amaçlandığı bu çalışmada, ölçme aracının geçerlik ve güvenirliğini belirlemek amacıyla madde analizi ve açımlayıcı faktör analizinden yararlanılmıştir.

13 maddeden oluşan ölçeğe uygulanan madde analizi sonucunda madde toplam korelasyon katsayısı 0,30'un altında olan hiçbir madde ile karşılaşılmamış bu nedenle madde analizi sonucunda ölçekten herhangi bir maddenin atılmasına ihtiyaç duyulmamıştır. 13 maddeden oluşan ölçeğin Cronbach'ın alfa güvenirlik katsayısı $(\alpha)=0.867$ bulunmuştur. Mallery (2003) güvenirlik katsayısına ilişkin ölçüt değerleri; $0.81<\alpha<1.00$ olduğunda ölçek yüksek güvenirliktedir şeklinde ifade etmektedir. Bu ölçüt değerler dikkate alındığında, ölçeğin yüksek güvenirlikte olduğu ve çocukların müzik yaşantılarına yönelik tutumlarının belirlenmesinde güvenirlik düzeyi yüksek ölçme sonuçlarına ulaşlabileceğini göstermektedir.

13 maddeden oluşan ölçeğin faktör analizine uygunluğunun belirlenebilmesi için Kaiser-Meyer-Olkin (KMO) Örneklem Yeterliliği Testi ve Barlett Küresellik Testinden yararlanılmıştır. 40 maddelik ölçeğin KMO değerinin 0.80 'nin üzerinde olması $(\mathrm{KMO}=0.876)$ ve Barlett testinin de 0.05 önem derecesinde anlamlı bulunması ( $\mathrm{p}=0.000$ ) ölçeğin faktör analizine uygunluğunu göstermiştir. Ölçeğin yapısal geçerliğinin belirlenmesi amacıyla temel bileşenler analizi ve varimaks eksen döndürme tekniği kullanılarak açımlayıcı faktör analizi uygulanmıştır.

13 maddeden oluşan ölçeğin faktör analizi sonucundaki faktör yük değerlerine bakıldığında, 10. maddenin faktör yük değerinin faktör yük sınırı ola- 
rak belirlenen 0.50 değerinin altında olduğu anlaşılmıştır. Ölçeğin faktör analizindeki dönüşümlü faktör yükleri sonuçlarına göre yine 10. maddenin birden fazla faktörde (1 ve 3 . faktörlerde) binişik yapıda olduğu belirlenmiştir. Bu nedenle 10. Madde, ölçeğin olabildiğince güçlü maddelerden oluşması amacına yönelik olarak ve maddenin ölçeğin güvenirliğini düşürebileceğinden yola çıkılarak ölçekten çıkarılmıştır.

10. maddenin ölçekten çıkarılmasıyla yeniden yapılan açımlayıcı faktör analizi sonuçlarına göre, 12 maddeden oluşan ölçeğin 3 faktörlü bir yapı sergilediği ve toplam varyansın \% 59.838' ini açıkladığı belirlenmiştir. Ölçekteki faktörler, 1. Faktör: Müzikal çevreye yönelik tutum, 2. Faktör: Müzik dersine yönelik tutum ve 3. Faktör: Şarkı yaşantısına yönelik tutum olarak adland1rılmıştır. Çocukların müzik yaşantısına yönelik tutum ölçeğinin faktörlerine ilişkin olarak 5 maddeden oluşan 1. Faktör toplam varyansın \% 39.787'sini, 4 maddeden oluşan 2. Faktör \% 11.525' ini ve 3 maddeden oluşan 3. Faktör de toplam varyansın \% 8.526'sını açıklamaktadır. Bir başka sonuç olarak 12 maddeden oluşan nihai tutum ölçeğinin Cronbach' in alfa güvenirlik katsayısı 0.860 olarak bulunmuştur.

Geliştirilen ölçek, müzik eğitimi ve müzik psikolojisi başta olmak üzere, çeşitli araştırma alanlarına ilişkin yeni olanaklar taşıyan bir araç olarak önemli görünmektedir. Örneğin müzikal çevre konusunda yapılacak bir çalışmada ölçeğin 1. faktörü olan "müzikal çevreye yönelik tutum" ile sosyal çevre ile müzikal etkileşime dönük araştırmalarda faydalanılabilir. Ulusal müzik eğitimi dağarına bakıldığında, çocukların müzikal çevreleriyle ilgili ilişkilerini duyuşsal bağlamda ölçecek bir ölçme aracı bulunmamaktadır. Oysa ki, müzik sosyal bir yaşantı olarak insan hayatının merkezine yerleşmiş bir olgudur. Örneğin Cross (2001) müziğin belirli sosyal etkileşimlere ve yapılara dayanan uygulamalar, kavramlar ve algılardan oluşan kültürel bir olgu olduğuna yönelik sosyal bilimlerdeki genel fikir birliğine dikkat çekmektedir. Hargreaves ve North (1999)'un da sosyal psikoloji bağlamında müzik eğitimini ele alma çabaları akılda tutulduğunda, araştırmada geliştirilen ölçeğin özgünlüğü ve sunduğu olanaklar daha rahat görülebilir.

Müzik eğitiminde müzik derslerine yönelik tutum birçok araştırmacının ilgi alanını oluşturmuş ve geliştirilen tutum ölçekleri özellikle sınıf düzeyine ilişkin olarak çeşitlilik göstermektedir. Çeşitlilik sunmak anlamında bu ölçekler örneklendirilmek istenirse, ilköğretim düzeyinde (Umuzdaş, 2012), ilköğretim altıncı sınıf düzeyinde (Öztürk, Kalyoncu, 2014); ilköğretim 4. ve 5. sınıf 
düzeyinde (Özmenteş, 2006) ve ortaöğretim (Varış, Cesur, 2012) düzeyindeki ölçümler ilişkin geliştirilmiş bazı araştırmalar sunulabilir. Ancak bu çeşitliliğe karşın, daha önce de vurgulandığı gibi sosyal bir yaşantı alanı olarak müzik olgusunun müzik derslerine yönelik tutum ile ilişkilendiği bir ölçek literatürde yoktur. Dolayısıyla bu ölçek ortaya konan bütünlüğüyle, müzikal sosyal etkileşim ve müziğe yönelik tutum arasında yeni bir kuramsal çalısma alanı sunmaktadır. Aynı zamanda ölçeğin çalışma grubu, yaş değişkeni dikkate alınarak düşünüldüğünde, bu bağlamda da yeni bir öneri getirdiği söylenebilir. Yine örneğin derse yönelik tutum ölçekleriyle kıyaslandığında, araştırmada geliştirilen ölçeğin, madde sayısının azlığının da zamandan tasarruf, değerlendirmede samimiyet vb. etkenlerle veri toplama aşamasında da önemli kolaylıklar sağlayacağı varsayılmaktadır.

Müzikal bir yaşantıda en önemli etkinliklerden ve unsurlardan biri olarak şarkı yaşantısı, özellikle çocukların öne çıkn müzikal ürünlerinden biridir. Çocukların müzik yapmaya dönük isteklerinin, dolayısıyla olumlu tutumlarının örtük olarak davranışlarından gözlemlenebileceği görüşü benimsenirse, şarkı söyleyen çocukların müzik yaşantısına daha fazla dahil olmak isteddikleri varsayılabilir. Ölçeğin 3. faktörü olarak beliren "şarkı yaşantısı" çocukların şarkı etkinliğine ilişkin tutumlarının belirlenmesinde katkı sağlayacaktır. Aynı zamanda şarkı söylemenin de çeşitli sosyal işlevleri düşünülürse, genel olarak üç faktörün bütüncül bir şekilde sosyal müzik yaşantısına yönelik tutumu göstermesi açısından önemli olduğu anlaşılabilir.

Tüm bu psikometrik sonuçlar dikkate alındığında, çocukların müzikal yaşantısına yönelik tutumlarının ölçülmesinde geçerli ve güvenilir bir şekilde kullanılabilecek bir ölçme aracının alana kazandırılmış olduğu düşünülmektedir. Araştırmanın konusunu oluşturan bu ölçme aracının, müzik psikolojisi ve müzik eğitimi bağlamında sosyal psikoloji alanında kesişen yeni araştırma konularına katkı oluşturacağı varsayılmaktadır. 


\title{
EXTENDED ABSTRACT
}

\section{Validity and Reliability Study of the Attitude Scale Towards Music Experience of 10-13 Age Group Children}

\author{
Hasan Hakan Okay - Özge Gençel Ataman - Barış Kardeş \\ Balıkesir University
}

As the subject of musical education, the learner continues to develop throughout the education process by interacting with various affective elements throughout the education process. Looking at various developmental theories today, it is emphasized that environmental factors and stimuli in life are also important developmental factors, in addition to accepting that some features are innate and cannot be changed (Özdemir et al., 2012).

For the modern man, who has interacted with music in various conditions and levels throughout his life, the developmental theoretical has reinforced the importance of social psychology due to the evidence regarding the effects of the environment on metabolism. This trend seems to have caught the attention of prominent music psychologists. For example, Hargreaves and North (1999) argued that social effects of music should be taken into consideration rather than its cognitive and affective effects, while demonstrating efforts to define the social in music psychology. Therefore, the effects of the environment and socialization can be sought in a musical life.

With the introduction of educational institutions into social life, music, which has been a part of people and society for thousands of years, has been the formal environment of the education process by taking part in educational programs. Therefore, music, which is already living for various purposes in different social and religious ceremonies, also began to play a role in educational life. However, in formal education life (for example, values education), various implicit educational meanings and purposes have been attributed to the functionality of music, both in socialization and due to its affective effects on the individual. 
The definition of music with its social and affective characteristics mentioned above and the expression of its qualities based on experience with musical environment and musical participation have led to the need for discussion of an attitude towards music life. Thus, if it is possible to determine and measure the attitude towards musical life, the factors affecting musical life can be addressed with a wide variety of variables. At the same time, such a measurement can offer teachers new possibilities as a tool to discover students' positive tendencies towards music that they somehow do not express. In this context, this study aims to develop a valid and reliable Musical Life Attitude Scale for children that addresses various musical practices such as singing, listening to music, and playing instruments in a social context.

This research is a scale development study. In the scale development phase of the study, the survey model was used as a descriptive research. The research aims at a quantitative description through a selected sample. Accordingly, the model of the study was shaped as a quantitative and descriptive research, taking into account the definition of the survey model of Creswell (2017).

The study group of this study consists of 524 secondary school students studying in state-affiliated secondary schools in the central districts of Balıkesır. Looking at the demographic characteristics of the sample; the distribution of female $(n=282)$ and male $(n=242)$ students and the age group consisting of $10(n=165), 11(n=152), 12(n=102)$ and $13(n=103)$ years in gender variable are given in Table 1 .

It has been determined that the scale consisting of 12 items has a 3 factor structure and explains $59.838 \%$ of the total variance. Factors in the scale were named as Factor 1: Attitude towards the musical environment, Factor 2: Attitude towards the music lesson, and Factor 3: Attitude towards song life. Regarding the factors of the scale of attitude towards children's music life, the first factor consisting of 5 items explains $39.787 \%$ of the total variance, the second factor consisting of 4 items explains $11.525 \%$, and the third factor consisting of 3 items explains $8,526 \%$ of the total variance. As another result, the alpha reliability coefficient of Cronbach's final attitude scale consisting of 12 items was found to be 0.860 .

The attitude towards music lessons in music education has been the area of interest of many researchers, and the attitude scales developed vary particularly in relation to the grade level. If these scales are to be exemplified in 
terms of presenting diversity, they can be used at the primary education level (Umuzdaş, 2012), at the sixth grade of primary education (Öztürk, Kalyoncu, 2014); some studies developed on measurements at primary education level 4 and 5 (Özmenteş, 2006) and secondary education (Arrival, Cesur, 2012) can be presented. However, despite this diversity, as emphasized before, there is no scale in the literature in which the phenomenon of music as a social life area is related to the attitude towards music lessons. Therefore, this scale presents a new theoretical field of study between musical social interaction and attitude towards music with its revealed integrity. At the same time, when the study group of the scale is considered by considering the age variable, it can be said that it brings a new proposal in this context. Again, for example, when compared to the attitude scales towards the course, the scale developed in the research offers a practical data collection process with the small number of items.

\section{Kaynakça / References}

Brand, M. (1986). Relationship between home musical environment and selected musical attributes of second-grade children. Journal of Research in Music Education, 34(2), 111-120.

Büyüköztürk, Ş. (2008). Sosyal bilimler için veri analizi el kitabı. Ankara: Pegem Akademi Creswell, J. W. (2017). Araştırma deseni nitel, nicel ve karma yöntem yaklaşımları. (3. Baskı). Ankara: Eğiten Kitap.

Cross I. (2001). Music, cognition, culture, and evolution. Annals of the New York Academy of Sciences, 930, 28-42. https://doi.org/10.1111/j.1749-6632.2001.tb05723.x

Crozier, W. R. (1997). Music and social influence. D. J. Hargreaves ve A. C. North (Eds.), The social psychology of music içinde (s. 67-83). Oxford University Press.

Dai, D. (2018). A history of giftedness: Paradigms and paradoxes. Ed. S. Pfeiffer, Handbook of Giftedness in Children: Psychoeducational Theory, Research, and Best Practices (2. bsm., s. 3-14). Cham: Springer.

Durmuş, B., Yurtkoru, S. ve Çinko, M. (2016). Sosyal bilimlerde SPSS'le veri analizi (6. bask1). İstanbul: Beta Basım Yayın.

Gardner, H. (1983). Frames of mind: the theory of multiple intelligence. New York: Basic.

George D, ve Mallery P. (2003). SPSS for windows step by step: A simple guide and reference. 11.0 update. (4th ed.). Boston: Allyn \& Bacon.

Gürbüz, S., ve Şahin, F. (2016). Sosyal bilimlerde araştırma yöntemleri (3. baskı). Ankara: Seçkin Yayıncilik. 
Hambrick, D. Z., ve Tucker-Drob, E. M. (2015). The genetics of music accomplishment: Evidence for gene-environment correlation and interaction. Psychonomic bulletin \& review, 22(1), 112-120.

Hallam, S. ve Shaw, J. (2002). Constructions of musical ability. Bulletin of the Council for Research in Music Education, 102-108.

Hallam, S. (2010). Music education: The role of affect. P. N. Juslin \& J. A. Sloboda (Eds.), Series in affective science. Handbook of music and emotion: Theory, research, applications (s. 791-817). Oxford University Press.

Hargreaves, D. J. ve North, A. C. (1999). The functions of music in everyday life: Redefining the social in music psychology. Psychology of Music, 27(1), 71-83.

Kaufman, S. B. veSternberg, R. J. (2008). Conceptions of giftedness. S.I. Pfeiffer (Eds.) Handbook of giftedness in children içinde (s. 71-91). Springer, Boston, MA.

Moore, D.S. (2015). The developing genome: An introduction to behavioral epigenetics. Oxford University Press.

Özdemir, O., Özdemir, P. G., Kadak, M. T. ve Nasıroğlu, S. (2012). Kişilik gelişimi. Psikiyatride Güncel Yaklaşımlar, 4(4), 566-589.

Özmenteş, G. (2006). Müzik dersine yönelik tutum ölçeğinin geliştirilmesi. İlköğretim Online, 1(2), 23-29.

Öztürk, Ö., ve Kalyoncu, N. (2014). İlköğretim altıncı sınıf müzik dersi için bir tutum ölçeği geliştirme denemesi. International Journal of Academic Social Science Studies, 235-248.

Pitts, S. (2005). Valuing musical participation. Hants, UK: Ashgate.

Renzulli, J.S. (1986). The three-ring conception of giftedness: A developmental model for creative productivity. R. J. Sternberg \& J. E. Davidson (Eds.), Conceptions of giftedness içinde (s. 53-92). New York: Cambridge University Press.

Seesjärvi, E., Särkämö, T., Vuoksimaa, E., Tervaniemi, M., Peretz, I. ve Kaprio, J. (2016) The nature and nurture of melody: A twin study of musical pitch and rhythm perception. Behavior Genetics. 46(4), 506-15.

Umuzdaş, S. (2012). İlköğretim müzik dersine ilişkin tutum ölçeğinin geliştirilmesi. International Journal of Human Sciences [Online]. 9(2), 1510-1523.

Varış, Y.A. ve Cesur, D. (2012). Ortaöğretim müzik dersine yönelik tutum ölçeğinin geliştirilmesi. Fine Arts, 7(4), 361-374.

Werner, P. D., Swope, A. J. ve Heide, F. J. (2006). The music experience questionnaire: Development and correlates. The Journal of Psychology, 140(4), 329-345.

Yaşar, M. (2014). İstatistiğe yönelik tutum ölçeği: geçerlilik ve güvenirlik çalışması. $P a$ mukkale Üniversitesi Eğitim Fakültesi Dergisi, 36(2), 59-75. doi: http://doi.org/10.9779/PUJE64c 
Yurdugül, H. (2005, Eylül). Ölçek geliştirme çalışmalarında kapsam geçerliği için kapsam geçerlik indekslerinin kullanılması. Pamukkale Üniversitesi Ë̆gitim Fakültesi XIV. Ulusal Ë̆̈itim Bilimleri Kongresine sunulan bildiri, Pamukkale Üniversitesi, Denizli. http://yunus.hacettepe.edu.tr/ yurdugul/3/indir/PamukkaleBildiri.pdf adresinden erişilmiştir.

\section{Kaynakça Bilgisi / Citation Information}

Okay, H. H., Gençel Ataman Ö. ve Kardeş, B. (2021). 10-13 yaş grubu çocukların müzik yaşantısına yönelik tutum ölçeğinin geçerlik güvenirlik çalışması. OPUS-Uluslararası Toplum Araştırmaları Dergisi, 17(34), 920-939. DOI: 10.26466/opus.834894 